\title{
On the Behavior of Cloud Patterns as Seen on Satellite Photographs in the Transformation of a Typhoon into an Extratropical Cyclone
}

\author{
By Mitsuru Sekioka \\ Institute of Meteorology, The Defense Academy, Yokosuka, Kanagawa \\ (Manuscript received 25 July 1969, in revised form 5 February 1970)
}

\begin{abstract}
The behavior of cloud patterns portrayed on the ESSA 2 photographs after typhoons Doris (September 1966) and Winnie (August 1966) encountered the pre-existing stationary fronts in the vicinity of Japan is discussed in relation to the results of the analysis based on the previously proposed hypothesis on the transformation of typhoons (Sekioka, 1956a): that a typhoon induces the formation of a new extratropical cyclone on the pre-existing front within the typhoon area producing a complex system of the typhoon and the cyclone. Some evidence is given in support of the validity of the hypothesis.

The field of $500 \mathrm{mb}$ relative vorticity is also investigated in regard to the movement of typhoon Doris and the formation of the new extratropical cyclone.
\end{abstract}

\section{Introduction}

It often happens that tropical cyclones entering middle latitudes are accompanied by warm and cold fronts and thus have the appearance of extratropical cyclones. Many authors have investigated the transformation of tropical cyclones into extratropical cyclones. In particular, Hughes et al. (1955), Knox (1955) and Palmén (1958) discussed several aspects of the remarkable transformation of hurricane Hazel (October 1954) near the Great Lake area.

A hypothesis (Sekioka, 1956a) was derived from the synoptic analysis of typhoon Marie (September 1954) which hit Japan. This typhoon showed similar behavior to Hazel's. This hypothesis, applied thereafter to various other typhoons (Sekioka, 1956b, 1957, 1959), has been enlarged into the following: a typhoon is not transformed essentially into an extratropical cyclone in middle latitudes, but induces the formation of a new extratropical cyclone on a pre-existing front which has invaded into the typhoon area, and thus produces a complex system consisting of the typhoon (hereafter called the main vortex) and the extratropical cyclone. The extratropical cyclone thus induced develops in usual fashion as an ordinary cyclone while the main vortex, which is usually in its decaying stage near Japan, dissipates gradually. The typhoon as a whole, therefore, is apparently transformed into an extratropical cyclone. On the other hand, when the pre-existing front does not invade into the inner region of the main vortex, no extratropical cyclone is formed and no transformation is observed, with the result that the main vortex having no warm and cold fronts goes on decaying on the way. The analysis. by Matano (1958) based upon this hypothesis also revealed that hurricane Hazel induced, on its transformation, the formation of a new extratropical cyclone on the pre-existing cold front.

Although the hypothesis, including the problem of the principle of superposition, has not yet been verified directly, it can be considered to hold good since it can satisfactorily explain the various complicated phenomena observed on the weather maps and on the meteorograms of some stations affected by the passage of many typhoons hitting. Japan (Sekioka, 1956 a, 1956 b, 1959).

An upper-air analysis will be necessary to understand three-dimensionally the process mentioned above, but aerological observation net is at present too sparse for a phenomenon on such a comparatively small scale. Fortunately, in recent years, cloud photographs near Japan have been obtained routinely from the meteorologial satellites. The purpose of this paper is to adduce evidence in support of the hypothesis by 
investigation and comparison of the behavior of cloud patterns as seen on the photographs due to ESSA 2 in the case of typhoons Doris (September 1966) and Winnie (August 1966), the former being apparently transformed into an extratropical cyclone and the latter not.

\section{Analysis of Typhoon Doris, September 1966}

(i) In Figs. 1a, 2a, 3a, and $4 a$ the surface maps exhibit the process of the transformation of typhoon Doris near Japan. The process can be interpreted from the point of view based on the hypothesis mentioned in Section 1. It is seen that Doris crossed northeastward over the western part of the Japanese Islands while weakening and moved toward a pre-existing stationary front lying over the Japan Sea (Fig. 1a). Then by 0000

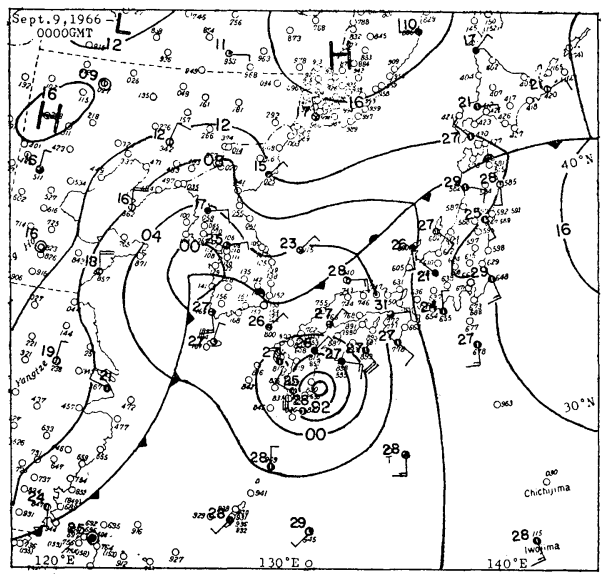

Fig. 1a. Surface weather map for 0000 GMT, September 9, 1966. Observed winds and temperatures are plotted.

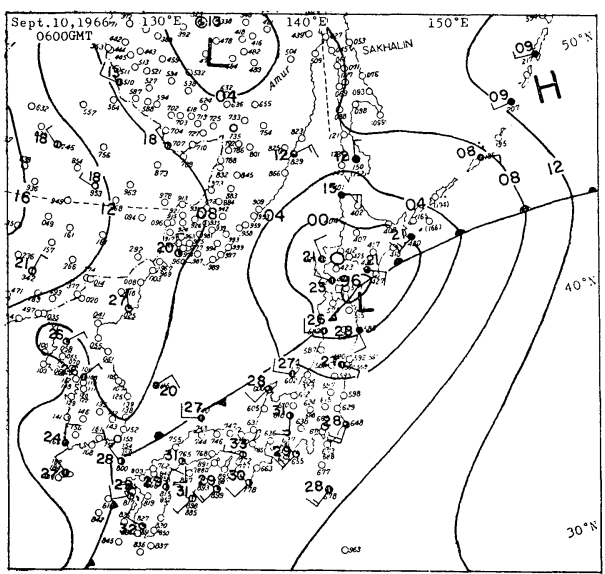

Fig. 3a. Surface weather map for 0600 GMT, September 10, 1966.
GMT, September 10, Doris seems to have been transformed into a frontal cyclone, accompanied by warm and cold fronts developing from the pre-existing stationary front (Fig. 2a). Thus an extratropical cyclone induced by Doris is supposed to have already been formed by the invasion of pre-existing front into the central part of Doris prior to that time. Six hours later, at $0600 \mathrm{GMT}$, the two separate pressure centers appeard (Fig. 3a). The eastern one has warm and cold fronts while the western one has not. The former is due to the developing extratropical cyclone and the latter to the decaying main vortex, and the appearance of these centers is the result of the nearly equal pressure-drops at the centers of the induced cyclone and the main vortex. At 0000 GMT, September 11 , an extratropical cyclone is located near the

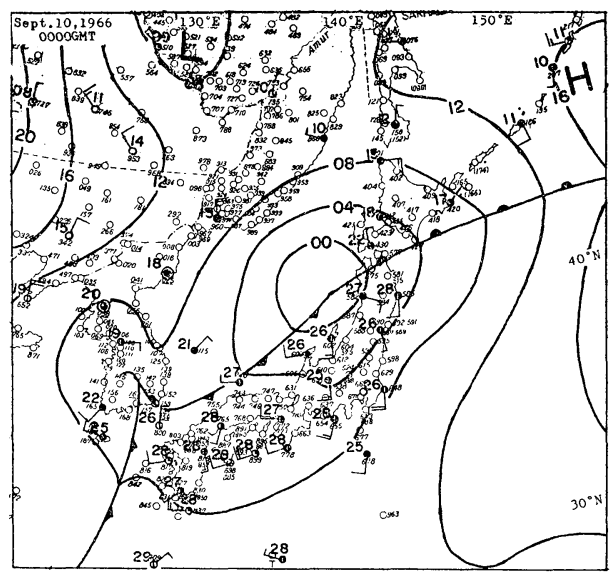

Fig. 2a. Surface weather map for $0000 \mathrm{GMT}$, September 10, 1966.

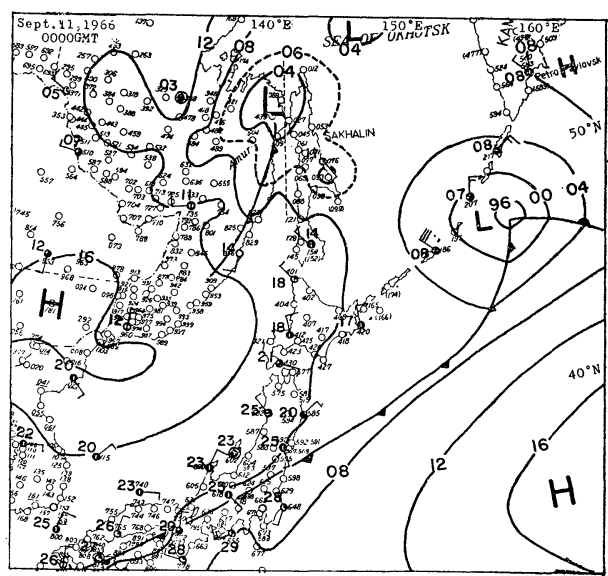

Fig. 4a. Surface weather map for $0000 \mathrm{GMT}$, September 11, 1966. 
Kuril Islands while a weak low having no warm and cold fronts has its center at $50^{\circ} \mathrm{N} ., 144^{\circ} \mathrm{E}$ in central Sakhalin (Fig. 4a). The extratropical cyclone looks like the remains of Doris, but the truth is that it is one induced by it. This latter low is still more conspicuous in the detailed pressure field near Sakhalin at that time (Fig. 5), and as it can not be identified as one coming from the west, it is supposed to be the residual depression from the main vortex hidden up to this time within the complex system.

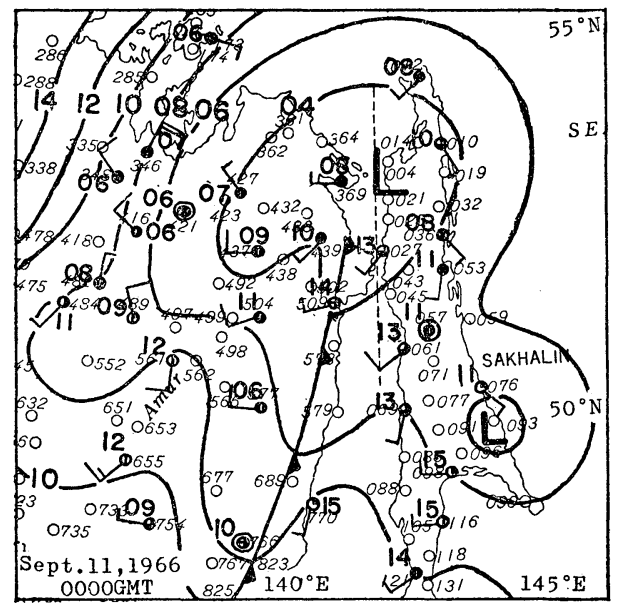

Fig. 5. Detailed local weather map for 0000 GMT, September 11, 1966.

Our next task is to investigate the behavior of the induced extratropical cyclone, eliminating the pressure pattern of the main vortex from the observed surface pressure field. The method will be indicated briefly in this paper, as full details have been given in previous papers (e.g., Sekioka, 1956a, Matano, 1958). Applying the Rankine combined vortex to the velocity field of a main vortex and integrating the cyclostrophic wind equation, the distribution of the pressure-drop $\left(p_{\infty}-p\right)$ owing to the main vortex is obtained

$$
\begin{array}{ll}
p_{\infty}-p=\pi\left(1-r^{2} / 2 b^{2}\right) & \text { for } r \leqq b \\
p_{\infty}-p=\frac{1}{2}\left(\pi b^{2} / r^{2}\right) & \text { for } r>b
\end{array}
$$

where $r$ is the distance from the center of the vortex, $b$ the radius of the inner region of the Rankine vortex, $p_{\infty}$ the pressure at infinity and $\pi$ the pressure difference at the center of the vortex from infinity. The relation between $b$ (in $\mathrm{km}$ ) and $\pi$ (in $\mathrm{mb}$ ) was semi-theoretically found by Matano (1956) to be

$$
\pi=6.25 \times 10^{-4} b^{2}
$$

To the decaying stage of the main vortex, Sekioka (e.g., 1956a) has applied the result of Matano (1956) that when no energy is supplied, the damping rate $K$ of $\pi$ of the rotating system with a constant radius $b$, whose energy is lost in the lateral mxing process, can be expressed in quasi-stationary treatment ( $t$ is expressed in hours and $b$ in $\mathrm{km}$ ) as

$$
\begin{array}{ll}
\pi=\pi_{0} \exp (-K t) & \text { (in mb) } \\
K=7.5 \times 10^{2} / b^{2} & \left(\text { in hour }{ }^{-1}\right)
\end{array}
$$

where $\pi_{0}$ is the initial value of $\pi$ at $t=0$. It is extremely plausible from the variation of the central pressure to infer that Doris reached its decaying stage at 1200 GMT, September 8 . Taking approximately the value of the outermost, nearly circular isobar for $p_{\infty}$, the value of $\pi$ is obtained as $25 \mathrm{mb}$ at that time, and the value of $b$ is calculated as $200 \mathrm{~km}$ by formula (2). Calculating the value of $K$ by formula (3.2) and adopting $t=0$ at $1200 \mathrm{GMT}$, September 8 , the successive values of $\pi$ for $t \geqq 0$ can be obtained by formula (3.1). Substituting the values of $\pi$ and the value of $b, 200 \mathrm{~km}$, into formula (1), the pressure-drop pattern owing to the main vortex in its decaying stage is obtained.

On the other hand, the path of the main vortex after the apparent transformation of Doris is determined first approximately by the following process: extrapolating its central positions at 1200 GMT, September 8 and at 0000 GMT, September 9 (Fig. 1a) and afterwards connecting them with

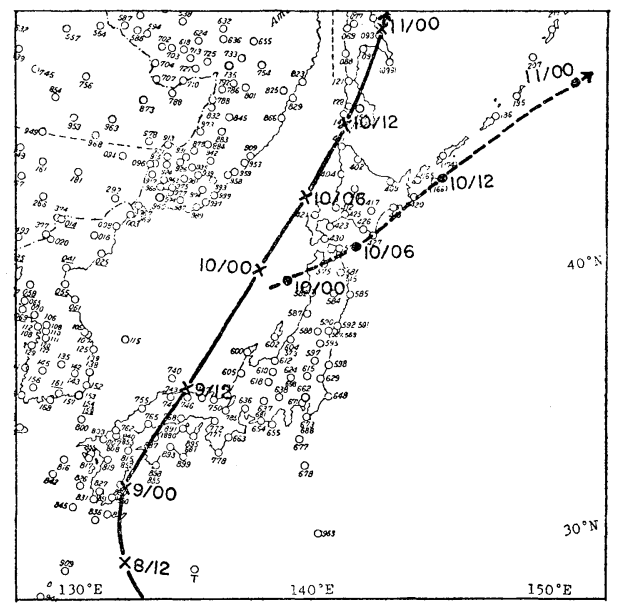

Fig. 6. Path of typhoon Doris. Solid line is the path of the main vortex and dashed line the newly-formed extratropical cyclone. 
the western one of the two separate pressure centers at 0600 GMT, September 10 (Fig. 3a) and the weak low in central Sakhalin at 0000 GMT, September 11 (Figs. 4a and 5). After some trials and errors, the determination of the central positions of the main vortex was successfully done as shown in Fig. 6, and the pressure-drop pattern owing to the main vortex could be removed from the observed pressure fields. The results are shown in Figs. 1b, 2b, $3 \mathrm{~b}$ and $4 \mathrm{~b}$. All the assumptions used here may be considered reasonable since the extratropical cyclone that thus appeared exhibits the same behavior as the usual cyclones near the Japanese Islands.

It is seen from Figs. $1 b$ and $2 b$ that the pre-

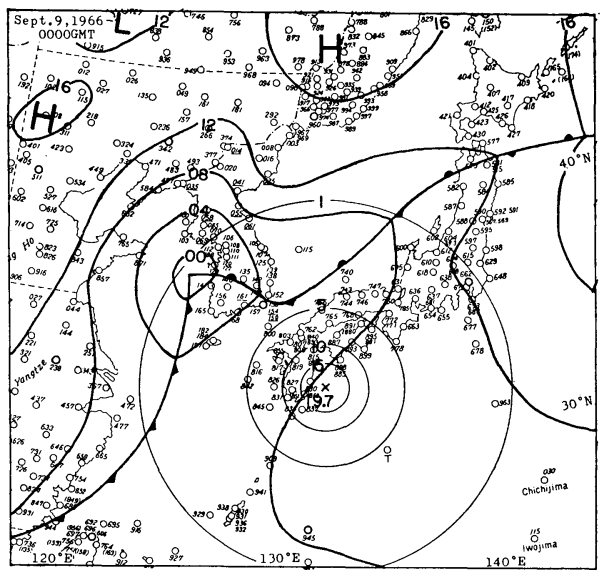

Fig. 1b. Separated pressure patterns for 0000GMT, September 9, 1966. Solid thin lines are isolines of the pressure-drop of the main vortex (in $\mathrm{mb}$ ), the central position of which is indicated by $x$, and solid thick lines are isobars of the remaining field.

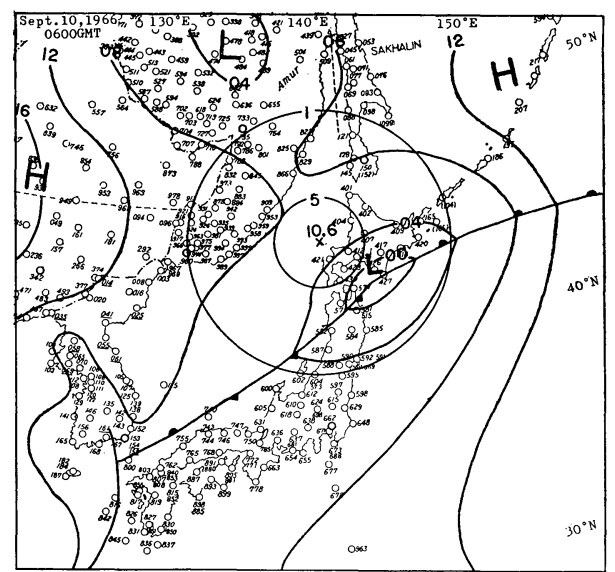

Fig. 3b. Separated pressure patterns for 0600 GMT, September 10, 1966. existing stationary front invaded into the inner region of the main vortex of Doris, with the result that a new extratropical cyclone appeared within this region, and thus a complex system was formed inside of 24 hours prior to 0000 GMT, September 10 over the Japan Sea. The inference that the formation of the cyclone was induced by Doris seems plausible because the inner region of the main vortex with large relative vorticity may be considered favorable for cyclogenesis. The appearance of two separate pressure centers (Fig. $3 b$ ) is due to the nearly equal values of the pressure-drop seen at the centers of the main vortex $(10.6 \mathrm{mb})$ and the accompanying cyclone $(10 \mathrm{mb})$. Moreover, as the main vortex moving

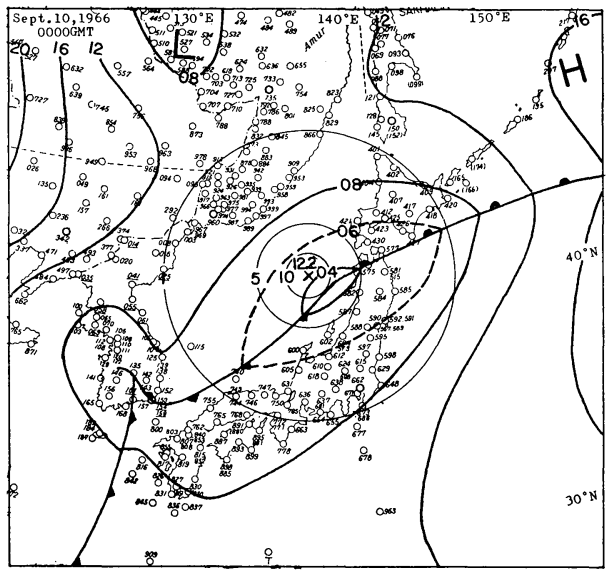

Fig. 2b. Separated pressure patterns for 0000 GMT, September 10, 1966.

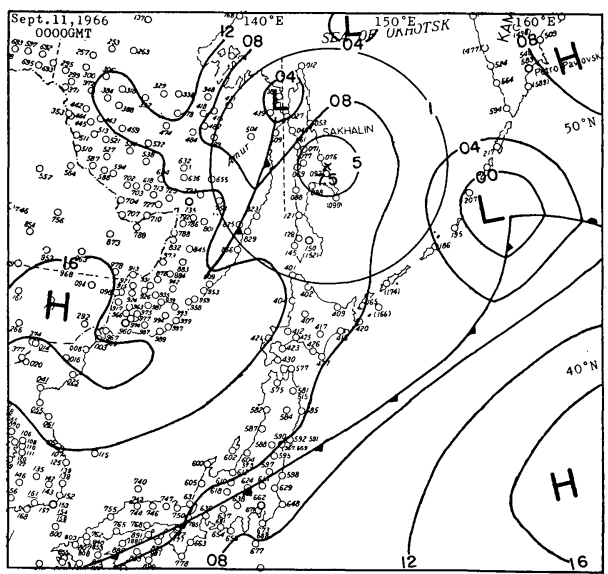

Fig. 4b. Separated pressure patterns for 0000 GMT, September 11, 1966. 
northeastward continued to dissipate and parted from the east-northeastward moving cyclone (Fig. $4 b$ ), the latter became predominant on the weather map (Fig. 4a) owing to its continuous development. Thus the apparent transformation of Doris into the extratropical cyclone was accomplished around 0000 GMT, September 11.

(ii) The behavior of cloud patterns during the passage of typhoon Doris near the Japanese Islands from September 9 to 11 is presented in a series of the ESSA 2 photomosaics at about 0000GMT each day (Figs. 7, 8 and 9). They are gridded to an accuracy of plus or minus 1 degree latitude. Comparisons of those cloud pictures with the separated pressure patterns of the main vortex and the remaiming field in Figs. 1b, 2b

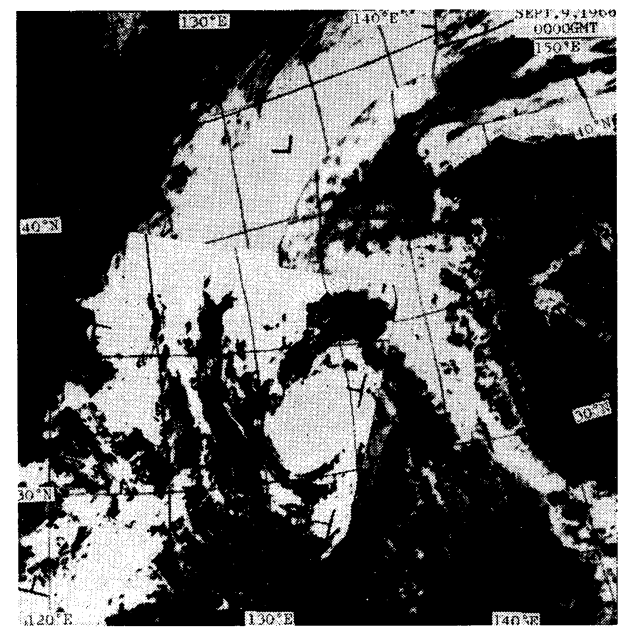

Fig. 7. ESSA 2 photomosaic at about 0000 GMT, September 9, 1966.

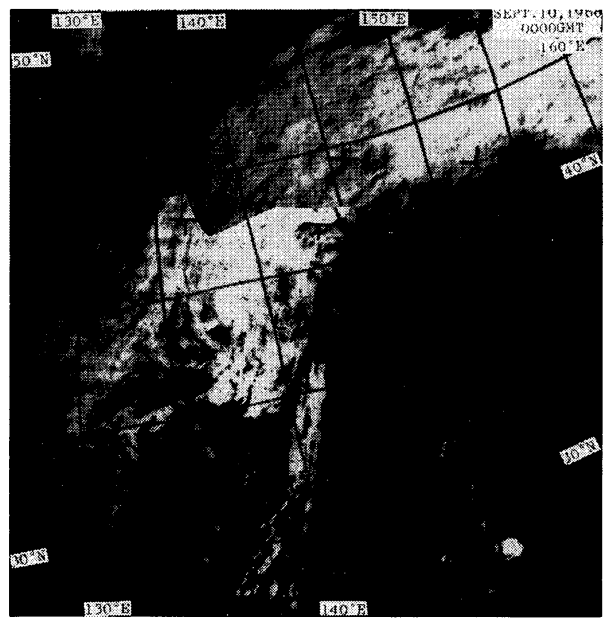

Fig. 8. ESSA 2 photomosaic at about 0000 GMT, September 10, 1966.

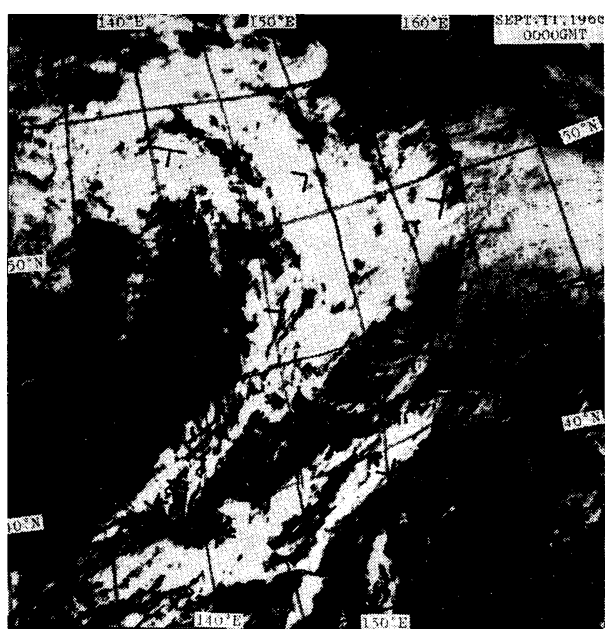

Fig. 9. ESSA 2 photomosaic at about 0000 GMT, September 11, 1966.

and $4 \mathrm{~b}$ were carried out. It is seen that the main vortex approaching toward the pre-existing stationary front blocking its way (Fig. 7) is embedded within the heavy overcast cloudiness of the front which extends to $37^{\circ} \mathrm{N}$., $133^{\circ} \mathrm{E}$ via $42^{\circ} \mathrm{N}$., $145^{\circ} \mathrm{E}$ (Fig. 8). This fact shows that the pre-existing front has already invaded into the inner region of the main vortex, at least at 0000 GMT, September 10, and confirms the analytical result shown in Fig. 2b. Such invasions, usually taking place over the sea, have so far been estimated only by interpolating the positions of the fronts on the weather maps. It is also observed that the heavy overcast cloudiness of the frontal system is well-regulated (Fig. 8) in spite of Sawyer's assertion (1947) that the warm and cold fronts of a typhoon are sheared out of existence by the rotating wind of the typhoon. This may be one of the collateral evidences for the reality of an induced frontal cyclone. The cloud pattern in the central part of Fig. 9 is that of a young frontal cyclone of about a day old and can not be regarded as what the typhoon was transformed into. This corresponds with the induced cyclone near $47^{\circ} \mathrm{N}$., $155^{\circ} \mathrm{E}$ in Fig. $4 \mathrm{~b}$ and, as a matter of course, is not a remnant of the typhoon. The major overcast cloudiness on the northwest side of this cyclone (Fig. 9) consists, on the other hand, of the two circulation systems near $50^{\circ} \mathrm{N}$., $144^{\circ} \mathrm{E}$ and $53^{\circ} \mathrm{N} ., 141^{\circ} \mathrm{E}$, respectively. The former seems to be attributable to the main vortex situated near central Sakhalin and the latter to a cyclone migrating from Siberia (see also Fig. 4b). The features of the cloud pattern 
around the center of the former circulation or the main vortex are similar to those of the decaying typhoon Judy (May 1966) reproduced in Fig. 10 (Fett, 1966), in that its center is situated

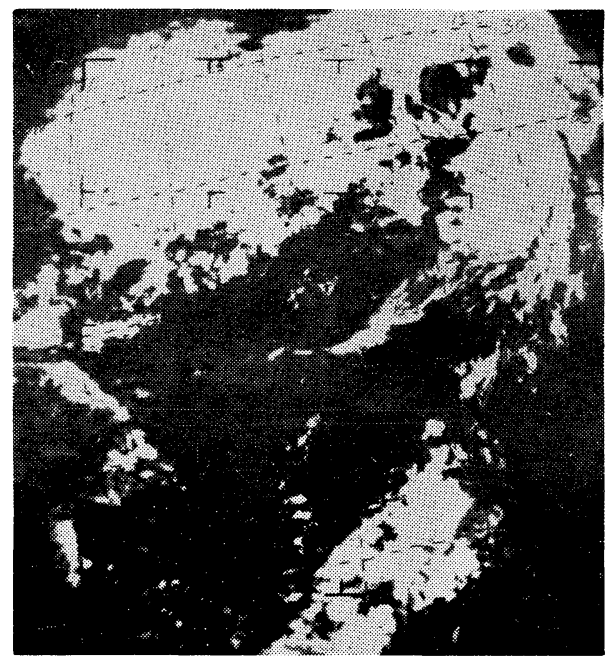

Fig. 10. ESSA 2 view of tropical storm Judy on May 31, 1966 at 0057 GMT. (after Fett (1966))

on the inside edge of the major overcast cloudiness except for the low latitude of Judy, i.e., around $25^{\circ} \mathrm{N}$. This seems to confirm the existence of the main vortex observed on the weather map (Figs. 4a and 5). Thus the principal analytical results obtained in (i) of this section have been corroborated by the cloud patterns viewed on the ESSA 2 photographs.

\section{Analysis of Typhoon Winnie, August 1966}

On August 26, typhoon Winnie, which had moved northwestward over the Yellow Sea toward a pre-existing stationary front extending along the coastline of China, recurved to the northeastward near the border between Korea and China and entered the crack of the cold airmass over Manchuria. Winnie was not accompanied with any warm and cold fronts throughout this period. These situations are exhibited in Figs. 11a, 12a and 13a.

From an anlysis of the pressure field at 0000 GMT, August 23 when the central pressure of Winnie began to rise, the values of $\pi$ and $b$ of its main vortex were estimated at $25 \mathrm{mb}$ and $200 \mathrm{~km}$, respectively, which are the same as those of Doris, being the normal values in typhoons hitting Japan and its vicinity (Matano, 1956). Taking $t=0$ at

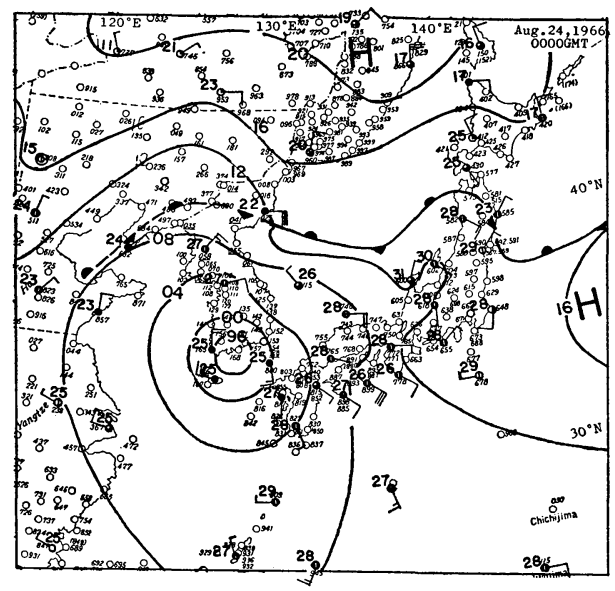

Fig. 11a. Surface weather map for $0000 \mathrm{GMT}$, August 24, 1966.

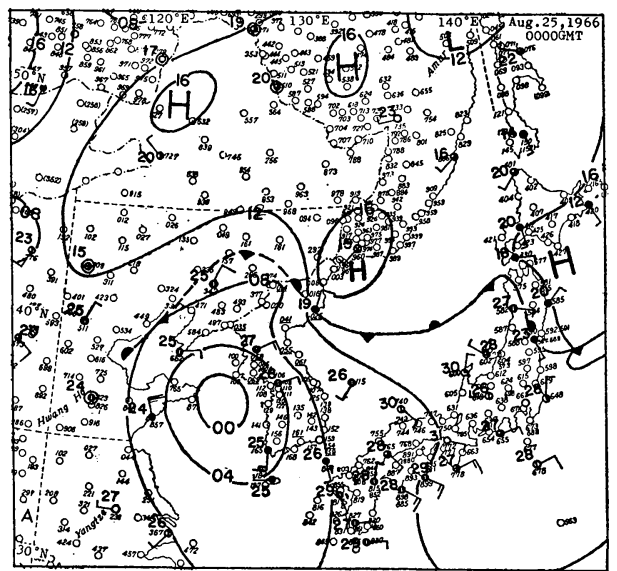

Fig. 12a. Surface weather map for $0000 \mathrm{GMT}$, August 25, 1966.

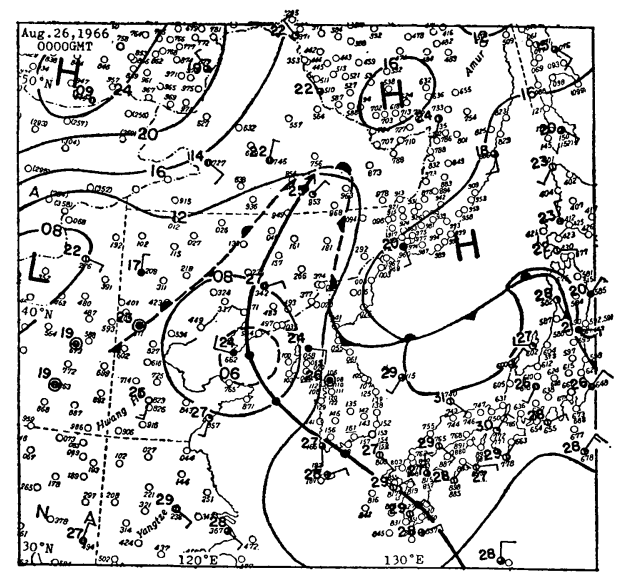

Fig. 13a. Surface weather map for 0000 GMT, August 26, 1966. Heavy line is the path of typhoon Winnie, and 24-hourly positions of its center from 0000 GMT, August 23 to 0000 GMT, August 27 are indicated by black dots. 


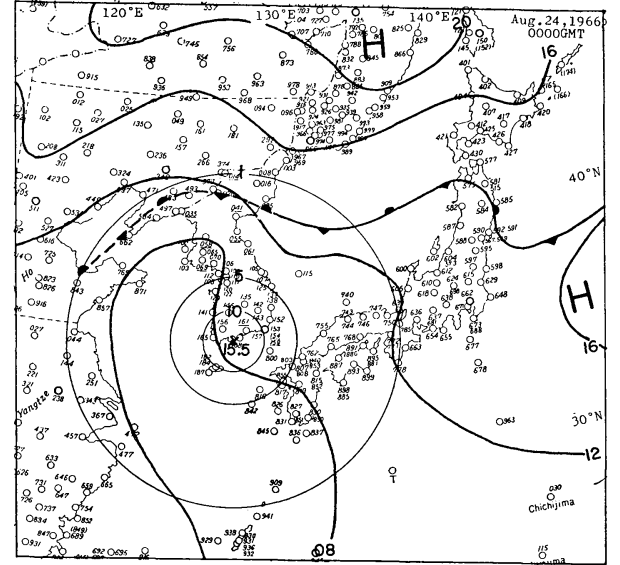

Fig. 11b. Separated pressure patterns for 0000 GMT, August 24, 1966.

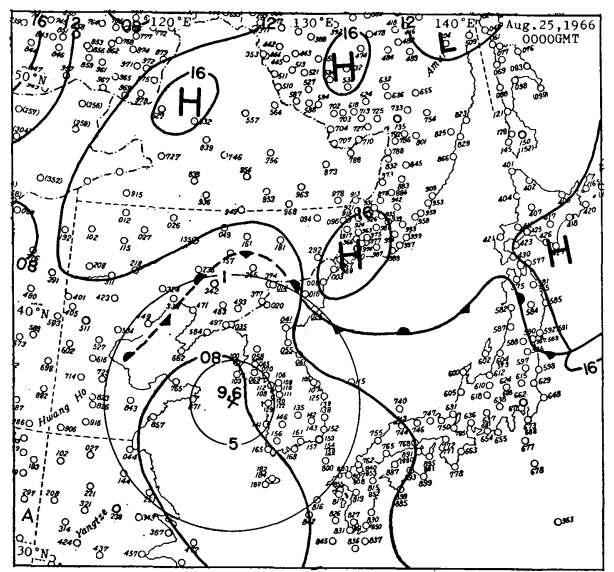

Fig. 12b. Separated pressure patterns for 0000 GMT, August 25, 1966.

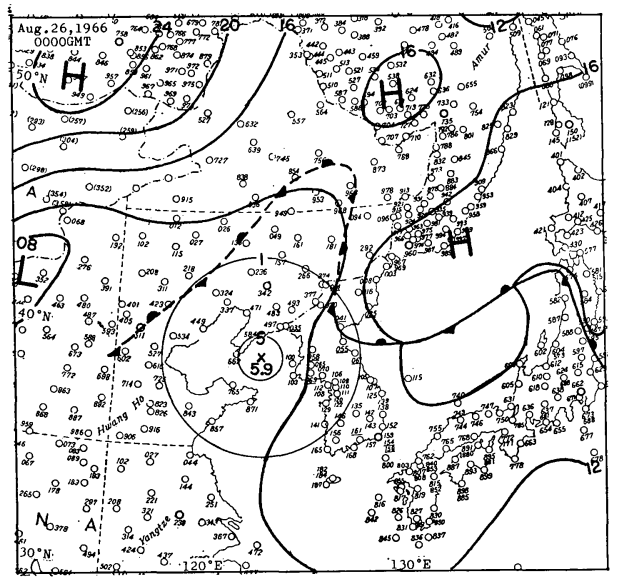

Fig. 13b. Separated pressure patterns for 0000 GMT, August 26, 1966.

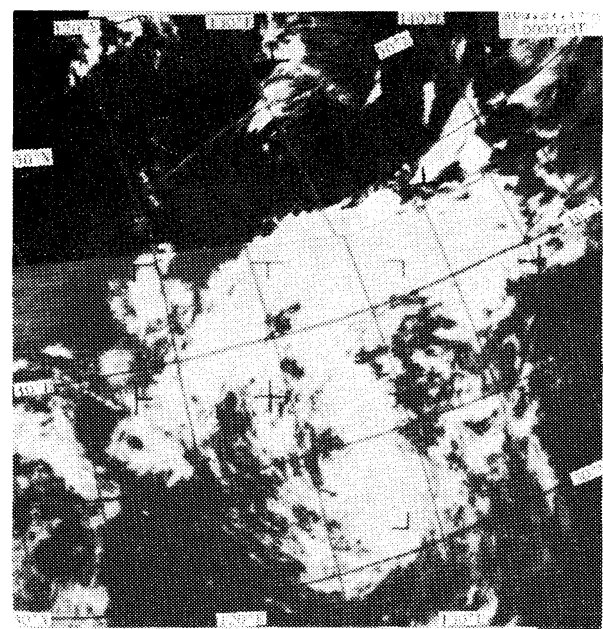

Fig. 14. ESSA 2 photomosaic at about 0000 GMT, August 24, 1966.

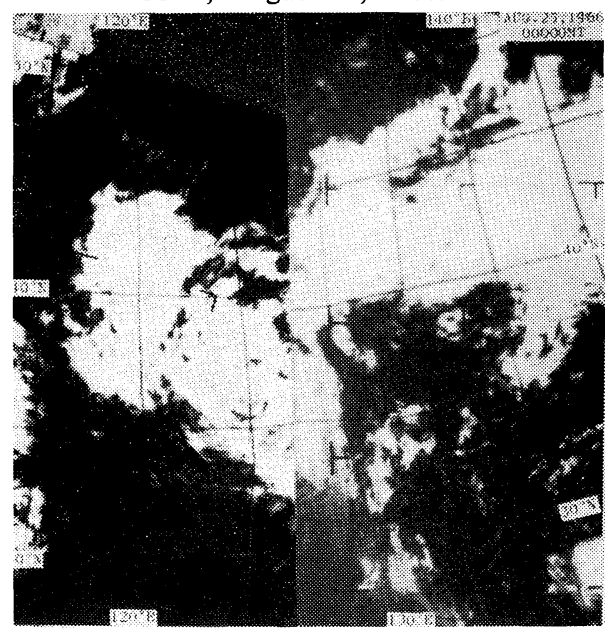

Fig. 15. ESSA 2 photomosaic at about 0000 GMT, August 25, 1966.

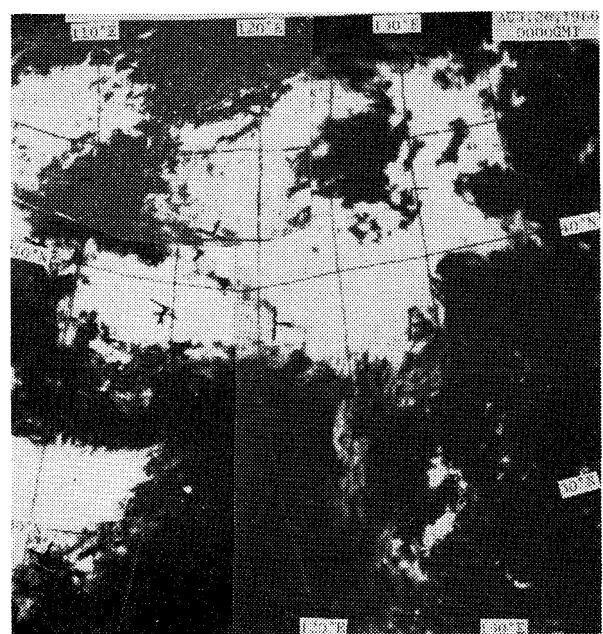

Fig. 16. ESSA 2 photomsaic at about 0000 GMT, August 26, 1966. 
0000 GMT, August 23, the successive values of $\pi$ can be calculated by formulae (3.1) and (3.2). The separation of the main vortex and the basic field from the observed pressure field on the weather maps can be carried out in much the same way as in the case of Doris, and the results are seen in Figs. 11b, 12b and 13b. It is revealed from those figures that Winnie decreased its intensity while it travelled along the east side of the pressure trough in the warm region without the pre-existing front invading into its inner region and inducing the formation of an extratropical cyclone to organize a complex system with the main vortex.

It can be seen from Figs. 14, 15 and 16, the ESSA 2 photomosaics during the period from August 24 to 26 , that the analytical result mentioned above is completely traced by the behavior of the cloud patterns of Winnie and the pre-existing front. Winnie approached the heavy overcast cloudiness of the pre-existing stationary front (Fig. 14), went along in the crack of the cloudiness (Fig. 15) and recurved from northwestward to northeastward without being absorbed like Doris into the cloudiness (Fig. 16). No cloud patterns related to extratropical cyclones appear during the period. The behavior of these cloud patterns, therefore, furnishes evidence supporting the conclusion that no transformation occurs when the pre-existing front does not invade into the inner region of the main vortex.

\section{Considerations of $\mathbf{5 0 0} \mathbf{~ m b}$ Relative Vorticity Field}

In Figs. 17, 18 and 19 is shown the 24-hourly $500 \mathrm{mb}$ relative vorticity field during the passage of typhoon Doris near Japan, which was prepared by the Japan Meteorological Agency. It is seen from those figures that, at least until 1200 GMT, September 10, a region of positive relative vorticity owing to typhoon Doris or the main vortex moved northeastward, that another positive region owing to an extratropical cyclone near the Korean peninsula (see Figs. 1a, 2a and 3a) stayed to the east of $130^{\circ} \mathrm{E}$ and that no positive region travelled from the west to the central part of the Japan Sea. This further confirms the conclusion that the new extratropical cyclone which appeared after removing the pressure pattern of the main vortex was one newly induced over the Japan Sea and not one that had come from the west.

A positive region moving eastward along $50^{\circ} \mathrm{N}$ (Figs. 18 and 19) is essentially attributable to a migrating cyclone from Siberia (see Figs. 2a, 3a and $4 \mathrm{a}$ ). There is a lack of exact information as to the region accompanying the main vortex between 1200 GMT, September 9 and 1200 GMT, September 10 because the grid interval of ca. $350 \mathrm{~km}$ and the time interval of 24 hours are too large. However, the isoline of $3 \times 10^{-5} \mathrm{sec}^{-1}$ at 1200 GMT, September 10 (Fig. 19) stretches out to the southwest coast of Sakhalin where the

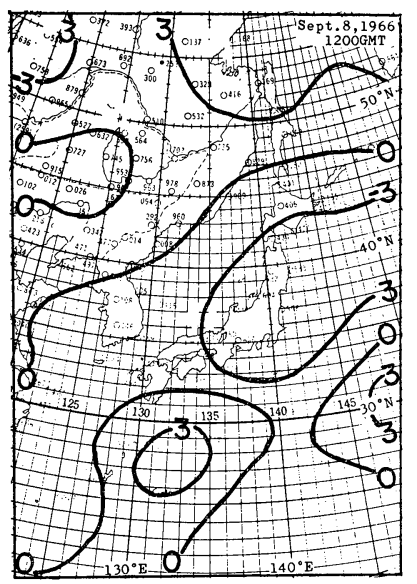

Fig. 17. $500 \mathrm{mb}$ relative vorticity field for 1200 GMT, September 8,1966 . Solid lines are isolines of relative vorticity (in $10^{-5}$ $\mathrm{sec}^{-1}$ ).

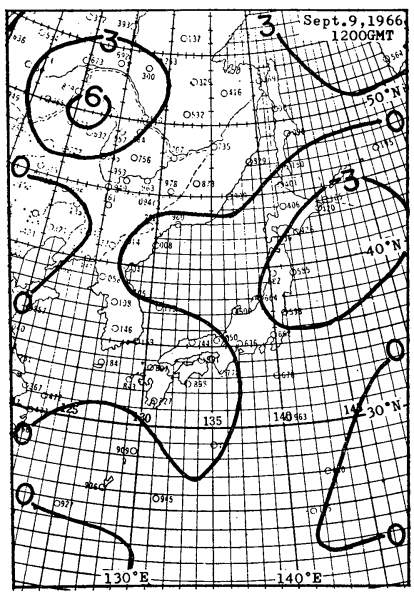

Fig. 18. $500 \mathrm{mb}$ relative vorticity field for $1200 \mathrm{GMT}$, September 9, 1966.

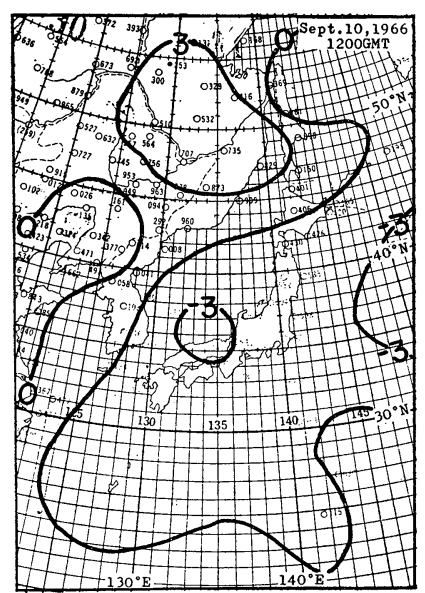

Fig. 19. $500 \mathrm{mb}$ relative vorticity field for $1200 \mathrm{GMT}$, September 10, 1966. 
main vortex is located at that time. This will confirm the existence of the main vortex.

In the case of typhoon Winnie, on the other hand, it is seen that a region of positive relative vorticity moved with the progress of the typhoon.

\section{Conclusions}

We have compared the behavior of the cloud patterns of the pre-existing front and typhoons Doris and Winnie portrayed on the satellite photographs with the results of the surface analyses based on the hypothesis concerning the transformation of typhoons. By this we have established some points in the hypothesis which have so far been only infered.

(1) When an extratropical cyclone, which is to make up a complex system together with the main vortex, is formed on the pre-existing front, that front has already invaded into the inner region of the main vortex.

(2) The warm and cold fronts of the induced extratropical cyclone are not sheared out of existence.

(3) The main vortex and the induced cyclone occur separately after they have parted from each other.

(4) When the pre-existing front does not invade into the inner region of the main vortex, no accompanying extratropical cyclone is formed and the decaying main vortex alone is observed.

On the other hand, an inspection of the field of $500 \mathrm{mb}$ relative vorticity in the case of Doris supports the analytical result that a new extratropical cyclone which is to produce a complex system with the main vortex was induced over the Japan Sea and also confirms the exitence of the main vortex in the vicinity of Sakhalin.

In brief, the previously proposed hypothesis on the transformation of typhoons in middle latitudes has been verified by the investigations of ESSA 2 photographs and the field of $500 \mathrm{mb}$ relative vorticity.

\section{References}

Fett, R.W. 1966: Life cycle of tropical cyclone Judy as revealed by ESSA II and Nimbus II, Month. Wea. Rev., 94, 605-610.

Hughes, L.A., F. Bear, G.E. Birchfield and R.E. Kaylor, 1955: Hurricane Hazel and a long-wave outlook, Bull. Amer. Meteor. Soc., 36, 528-533.

Knox, J.L. 1955: The storm "Hazel", Bull. Amer. Meteor. Soc., 36, 239-246.

Matano, H. 1956: On the role of the lateral mixing in the cyclostrophic flow pattern in the atmosphere, J. Meteor. Soc. Japan, 34, 1-12.

1958: On the synoptic structure of hurricane Hazel, 1954, over the eastern United States, J. Meteor. Soc. Japan, 36, 23-31.

Palmén, E. 1958: Vertical circulation and release of kinetic energy during the development of hurricane Hazel into an extratropical storm, Tellus, 10, 1-23.

Sawyer, J.S. 1947: Note on the theory of tropical cyclone, Quart. J. Roy. Meteor. Soc., 73, 101-126.

Sekioka, M. 1956a: A hypothesis on complex of tropical and extratropical cyclones for typhoon in middle latitudes. I. Synoptic structure of typhoon Marie over the Japan Sea, J. Meteor. Soc. Japan, 34, 42-53.

1956b: A hypothesis on complex of tropical and extratropical cyclones for typhoon in middle latitudes. II. Synoptic structure of typhoons Louise, Kezia and Jane passing over the Japan Sea, J. Meteor. Soc. Japan, 34, 40-49.

1957: A hypothesis on complex of tropical and extratropical cyclones for typhoon in middle latitudes. III. Examples of typhoon not accompanied by extrapical cyclone in middle latitudes, J. Meteor. Soc. Japan, 35, 20-23.

1959: A hypothesis on complex of tropical and extratropical cyclones for typhoon in middle latitudes. IV. Analyses on typhoons invading into the Japan Sea during the period from 1947 to 1956, J. Meteor. Soc. Japan, 37, $111-114$. 


\title{
日本付近で台風が温帯低気圧に变る際に気象衛星から見られる雲の状態
}

\author{
関岡満 \\ 防衛大学校気象学研究室
}

台風 Doris（1966年 9 月）とWinnie（1966年 8 月）が日本付近で既存の停滞前線に出会った後の状態を, “台風そ れ自体が温帯低気圧に变るのではなく，台風域内で既存の前線上に新らたに温帯低気圧が誘発され，これと台風との 複合系が生じ，やがて台風本体は衰退し，温帯低気圧のみが天気図上に現われて来，見掛上の台風の温帯低気圧化が 完成する”といら著者が1956年に提出した仮説に基いて解析した。高層観測網はこの程度の規模の現象には少し粗い ので, ESSA 2 号から得た雲の写真を地表面解析の結果と対比して論じた。雲の状態からこの仮説を支持する $2,3 の$ 証拠を得た.

$500 \mathrm{mb}$ 相対らず度場を検討して，台風 Doris の場合，これとの複合系を形成した温帯低気圧が，西方から東進し てきたものではなく，日本海で発生したものであることを更に確実にし，また，台風本体の移動をこの場に関連して 述ベた. 